\title{
AMLODIPINE OVERDOSE - A TRICKY CASE SCENARIO
}

\author{
Jojo Joseph Antony'1, Netto George Mundadan², Riyaz Sherief3, Payal Mukker4, Jijun T. Ignatius ${ }^{5}$
}

${ }^{1}$ Associate Professor, Department of Medicine, Sree Gokulam Medical College and Research Institute, Venjaramood. ${ }^{2}$ Senior Resident, Department of Medicine, Sree Gokulam Medical College and Research Institute, Venjaramood. ${ }^{3}$ Senior Resident, Department of Medicine, Sree Gokulam Medical College and Research Institute, Venjaramood. ${ }_{4}^{4}$ Associate Professor, Department of Medicine, Sree Gokulam Medical College and Research Institute, Venjaramood. 5 Postgraduate Resident, Department of Medicine, Sree Gokulam Medical College and Research Institute, Venjaramood.

\section{ABSTRACT}

\section{BACKGROUND}

Calcium channel blockers are frequently used in management of essential hypertension, of which amlodipine is a common agent. Overdose of amlodipine results in refractory hypotension and non-cardiogenic pulmonary oedema. The mainstay of treatment involves glucose insulin drip, calcium supplementation and glucagon. Here, we report a case of a 25-year-old female with history of intake of $100 \mathrm{mg}$ of amlodipine treated successfully with glucose insulin drips and calcium infusion.

\section{KEYWORDS}

Amlodipine, Calcium, Insulin.

HOW TO CITE THIS ARTICLE: Antony JJ, Mundadan NG, Sherief R, et al. Amlodipine overdose - a tricky case scenario. J. Evolution Med. Dent. Sci. 2017;6(18):1464-1465, DOI: 10.14260/Jemds/2017/320

\begin{abstract}
BACKGROUND
Calcium Channel Blockers (CCBs) are considered to be the mainstay in management of hypertension. Amlodipine is a common dihydropyridine calcium channel blocker used in India in varying dose up to a maximum of $20 \mathrm{mg}$ daily. Unlike other calcium channel blockers, amlodipine has a very low metabolic clearance with the advantage of using a once-daily dosage to maintain a near-constant plasma concentration. Owing to the easy availability, it is becoming a nemesis as it is being used for suicidal purposes by means of overdose. Proper management guidelines have not been formulated yet for this condition and different drugs including glucagon, insulin and calcium gluconate in titrated doses are being used with reasonable success rate. Here, we report a case of a 25year-old female who presented with history of intake of 100 mg of amlodipine, was in hypotension and how she was managed successfully.
\end{abstract}

\section{CASE REPORT}

A 25-year-old female presented to the casualty of a Tertiary Care Centre in South Kerala with history of intake of 20 tablets of amlodipine 2 hours prior to admission. On presentations, she was lethargic and her pulse rate was $108 / \mathrm{mt}$, BP was $90 / 50 \mathrm{mmHg}$ and room air saturation was $96 \%$. She was started on intravenous fluids and a gastric lavage was given. As blood pressure had dropped to 76/52 $\mathrm{mmHg}$, she was taken to the intensive care unit and started on dobutamine infusion at 5 microdrops $/ \mathrm{mt}$ and titrated upwards. She was given $20 \mathrm{~mL}$ of $10 \%$ calcium gluconate stat intravenously, and an infusion was set up at $10 \mathrm{~mL} / \mathrm{hour}$. After one hour, her BP read as 78/48 mmHg.

Her laboratory investigation reports read as blood glucose $92 \mathrm{mg} \%$, blood urea $21 \mathrm{mg} \%$, serum creatinine 0.8

Financial or Other, Competing Interest: None.

Submission 02-12-2016, Peer Review 15-02-2017,

Acceptance 21-02-2017, Published 02-03-2017.

Corresponding Author:

Netto George Mundadan,

CN 46,

Angamaly-683572.

E-mail: nettomundadan@gmail.com

DOI: $10.14260 /$ jemds $/ 2017 / 320$ $\mathrm{mg} \%$, sodium $134 \mathrm{mEq}$, potassium 4,6 mEq, calcium $9.1 \mathrm{mg} \%$ and ionised calcium $4.3 \mathrm{mg} \%$. Haemogram reports were normal. ECG showed sinus tachycardia. ABG analysis showed mild metabolic acidosis.

She was given $200 \mathrm{~mL}$ of $25 \%$ dextrose infusion over 10 minutes and was started on insulin with a loading dose of 30 units and an infusion of 30 units/hour. A maintenance drip of $5 \%$ dextrose was set up considering possibility of hypoglycaemia as she was not a diabetic and was receiving high-dose insulin infusion. Within 3 hours of starting the insulin infusion, her blood pressure improved to $92 / 64$ $\mathrm{mmHg}$ and by next day BP was $112 / 84 \mathrm{mmHg}$ without inotropic support. Insulin infusion was gradually tapered down, heart rate came down to $80 / \mathrm{mt}$ and patient was discharged by the fourth day of admission after giving psychiatric counselling.

\section{DISCUSSION}

Dihydropyridine CCBs have a predominant effect on vascular smooth muscle cells with little effect on cardiac pacemaker cells or contractility. ${ }^{1}$ That explains why our patient presented with a refractory hypotension without cardiac conduction defects. ${ }^{2}$ Treating patients with overdose of CCBs can challenge even experienced physicians. The difficulty arises because patients severely poisoned with CCBs can develop profound refractory bradycardia, hypotension and either cardiogenic or non-cardiogenic pulmonary oedema. ${ }^{3}$

Gastrointestinal decontamination with activated charcoal constitutes the first line of therapy for patients with $\mathrm{CCB}$ overdose. ${ }^{4}$ However, the best effect of this is seen if given within one hour of overdose, whereas our patient presented after two hours.

The various methods used in the management of CCB overdose are hyperinsulinaemia-euglycaemia technique, 5 continuous IV infusion of calcium ${ }^{6}$ and inotropic support with dopamine, norepinephrine, dobutamine and levosimendan. Insulin increases plasma levels of ionised calcium, improves the hyperglycaemic acidotic state, improves myocardial utilisation of carbohydrates and exerts its own independent inotropic effect. This principle was used to the maximum effect in this case and the patient responded very well to the 
regime while she was resistant to IV fluids, inotropes and calcium supplementation.

It has been said that several cases of amlodipine overdose lead to non-cardiogenic pulmonary oedema and acute kidney injury, which was not seen in this case. The duration of hospital stay was markedly reduced as the patient showed an overnight improvement in blood pressure since the start of insulin. Another drug that has been postulated to be effective in managing this condition is glucagon, which was not tried in this case owing to technical difficulties.

Hence, we suggest the use of glucose insulin regime along with calcium supplementation for effective management of amlodipine overdose.

\section{CONCLUSION}

Hence we suggest that glucose insulin regime can be effectively used for managing cases of amlodipine overdose thereby reducing the morbidity and mortality.

\section{REFERENCES}

[1] Russell RP. Side effects of calcium channel blockers. Hypertension 1988;11(3):II42-4.
[2] Houari T.EL, Haddiya I, Ouafi N. El, et al. A survival case in a severe amlodipine intoxication. Case reports in Cardiology Article ID 842606 2013(2013):2. http:// dx.doi.org/ 10.1155/2013/ 842606. Hindawi Publishing Corporation.

[3] Naha K, Suryanarayana J, Aziz RA, et al. Amlodipine poisoning revisited: acidosis, acute kidney injury and acute respiratory distress syndrome. Indian J Crit Care Med 2014;18(7):467-9.

[4] Patel NP, Pugh ME, Goldberg S, et al. Hyperinsulinemic euglycemia therapy for verapamil poisoning: a review. Am J Crit Care 2007;16(5):498-503.

[5] Azendour H, Belyamani L, Atmani M, et al. Severe amlodipine intoxication treated by hyperinsulinemia euglycemia therapy. J Emerg Med 2010;38(1):33-5.

[6] Ghosh S, Sircar M. Calcium channel blocker overdose: experience with amlodipine. Indian J Crit Care Med 2008;12(4):190-3. 